The second section describes isolated ocular anomalies; the globe as a whole, the cornea, lens, uveal tract, retina, optic nerve, and other tissues are taken in turn, and each is illustrated with pedigrees. A final section discusses generalized disorders with ocular aspects, under the headings of metabolic diseases, systemic disorders, and miscellaneous syndromes. A selected bibliography and index complete the volume.

This work is so written that no special knowledge of heredity is required to understand it. The fundamentals of the subject are discussed and illustrated before individual and problematical pedigrees are examined. On every page the enormous advances made in recent years and the widening field which the study of genetics embraces are evident, and are contrasted with the equally enormous defects in our detailed knowledge. The book is comprehensive, up-to-date, and well in line with the tradition of British ophthalmological genetics laid by Edward Nettleship and C. H. Usher. It is hopeful in its outlook for future research and the control of hereditary disease, and is informed by the deep sense of social responsibility which we have learned to expect from its author.

\title{
OBITUARY
}

\section{E. H. HARRIES-JONES}

If Evan Harries Harries-Jones had lived for one more day, he would have completed half-a-century's service as ophthalmic surgeon to the Northampton General Hospital; and a few more weeks of health would have enabled him to attend the 36th Oxford Ophthalmological Congress, at which he was greatly missed by his friends. Readers of this journal all over the world will remember him with affectionate gratitude, and their sympathy is extended to his widow and to his daughter, Mrs. S. H. G. Humfrey.

H.-J. stood out as a tower of strength amidst changes which have constituted a revolution in the social system as well as in the conduct of medical practice. Born at Rhyl in 1874, he entered medicine as an apprentice to Dr. Hughes of Ruthin at the age of 16, and later studied at Edinburgh and Dublin. He graduated M.B., C.M. in 1897, and was awarded the M.D. of Edinburgh University in 1900. A series of resident posts at the Birmingham Eye Hospital allowed H.-J. scope to develop the clinical judgment for which he became renowned beyond the confines of his county, and the Singlehurst Block, presented to the Northampton General Hosp tal in 1924 by a grateful patient, stands as an enduring reminder of his work.

Throughout his long professional life H.-J. found time for other activities, including the study of history. He was highly honoured by his fellow-ophthalmologists who chose him to be President of the Midland Ophthalmological Society, President of the South Midlands Branch of the B.M.A., and a Vice-President of the Ophthalmological Society of the United Kingdom. He was also a founder-member and counsellor of the Oxford Ophthalmological Congress, but these and the other distinctions which fell to his lot were transcended by H.-J's own splendid personality. In his company barriers of age and rank were swept aside, and his laugh resounded with human generosity. All his colleagues will treasure the memory of their association with Harries-Jones. 